\title{
The Macro Determinants of M \& A Timing in China
}

\author{
Jing Wang \\ Economic department, Ocean University of China, Qingdao 266071, China \\ E-mail: sophiafinance@163.com
}

\begin{abstract}
The timing of $\mathrm{M} \& \mathrm{~A}$ is the important aspect of M\&A theory. In recent years China's mergers and acquisitions rapidly developed, while there was rare in-depth analysis and scientific verification of the affecting factors of the increasing acquisition. In this paper, according to the subject research in the global, we do empirical test of the macroeconomic factors that may affect the corporate acquisition, and we find that economic growth, interest rates, money supply, exchange rates will affect the number of China's corporate mergers and acquisitions, while the relationship between the $\mathrm{M} \& \mathrm{~A}$ and the stock market and economy freedom are not significant.
\end{abstract}

Keywords: Corporate mergers and acquisitions, Macroeconomic, Empirical Study

\section{Introduction}

Since 1993 China launched the first M \& A, up to now it has been almost 15 years. Especially since 1996, the number of M \& A has grown significantly year after year. While the amount and scale of the Global M \& A activity decreased largely, the rapid increase of China's M \& A draws our great concern. As shown in table 1.

Table 1. The amount of Chinese enterprises' M\&A from 1995 to 2006

\begin{tabular}{|ll|ll|lc|}
\hline year & amount & year & amount & year & amount \\
\hline 1995 & 1 & 1999 & 84 & 2003 & 170 \\
\hline 1996 & 9 & 2000 & 103 & 2004 & 161 \\
\hline 1997 & 33 & 2001 & 119 & 2005 & 266 \\
\hline 1998 & 70 & 2002 & 168 & 2006 & 1411 \\
\hline
\end{tabular}

Data resource: $<$ China security newspaper $>1996-2007$

Fluctuations of the corporate mergers and acquisitions wave require mergers and acquisitions theory to make full explanation. As corporate mergers and acquisitions in the global economy are playing an increasingly important position, there is more and more analysis of the M \& A macro-factors.

Nelson (1959), according to the data analysis from 1895 to 1956, found that there were significant relation between merger and acquisition activity and the economic cycle, the industrial output value, stock prices, stock transactions and the industry merger, and pointed out that in active merger and acquisition activity the positive relation between M\&A and stock prices are more significant than it between M\&A and the industrial output value.

Melicher, Ledolter, Antonio (1982) through the analysis found that the relevance between M\&A activity and industrial output, the number of bankrupt enterprises were weak, while the relevance between the M\&A activity and the stock and bond yield in the capital market were strong. High stock prices and low bond yields can predict the future as merger and acquisition activity indicators. Through the data analysis from 1951 to 1959 Michael Gort found that the correlation of the M \& A activity and the stock price did not exist obviously.

In his doctoral thesis, Chung, Kwang S (1981) did empirical test of the conglomerate mergers from 1957 to 1977, and found that products expansion conglomerate merger can have a good explanation using the gross national product and the cost of capital, and the pure conglomerate merger depended more on high-risk enterprise risk premium and the degree of monetary tightening.

Becketti (1986) stated that the current M\&A activity and the previous stock price index, capacity utilization and total debt related positively, while the M\&A activity and the past discount rate of treasury note, gross national product were negatively correlated.

George Bittlingmayer (1987) treated corporate mergers and acquisitions as way of investment, and certificated that there were correlation between M\&A activity and industrial production, research and development expense, productivity, and noted that in many countries there existed a positive correlation between the M\&A activity and the overall amount of investment.

Globe, White (1993) according to the data analysis in 1895-1989, confirmed the M\&A activity showed the characteristics of waves and pointed out that $\mathrm{M} \& \mathrm{~A}$ activity was affected by the changes in the market, the cost of capital, the tax system, and other factors. 
Geraldo, Rechard (1996) analyzed the cross-border enterprises M \& A in the United States and Canada in 1982-1990, and found that bond financing costs and price-earnings ratio of companies made a greater impact on mergers and acquisitions, the impact of stock prices and exchange rate changes towards M\&A were relatively small.

In China, the study of macro factors affecting M\&A activity is relatively rare. Gu Wenjun (2003) compared the GDP and the two waves of enterprises M\&A activity in 1953-1997, and found that in this period the acquisition of Chinese enterprises and the economic cycle showed a non-positive correlation. Li Ruihai, Chen Hongmin, and Zou Lirui (2006) did simple comparative analysis of the M\&A above 1 million U.S. dollars and GDP growth, Shenzhen and Shanghai average index, the economic freedom in 1999-2004, and concluded that for China, M\&A activity and economic growth rates, economy freedom were positively correlated, whereas the relevance between M\&A and the stock price index was not significant. In his doctoral thesis Shaoxiang Tang (2006) made use of different time series analysis of the M \& A transactions amount in 1998-2005, drew conclusion that from the long-term perspective, there were long-term balanced relationship between China's overall M\&A activity and stock index, interest rates, Money supply and exchange rate, while in the short term, M\&A shows negative correlation with stock index , significant negative correlation with interest rates, a weak positive correlation with money supply ,and negative correlation with the exchange rate, but not significant. But the article did not make a detailed explanation towards the transmission mechanism of the M\&A and the exchange rate and money supply.

With previous research results, the paper does empirical analysis of China's M \& A amount from 1996 to 2006, with a view to reveal the macro factors affecting China's corporate $M$ \& A.

\section{Variable selection, data and model description}

\subsection{Research assumptions}

To facilitate the exposition, we make the following assumptions:

Assumption 1: M \& A activity and economic cycle correlate positively.

At the time of Economic prosperity, corporate remain optimistic attitude to future economic and market outlook, and actively expand its operations. Takeover of the target enterprises, as a low-cost quick investment, is welcomed by all enterprises. The economic downturn is just the opposite. Enterprises have little confidence towards the future prospects, will contract production, and reduce acts of mergers. Here the gross domestic product as representative of growth in the economy. Assumption 2: M \& A activity and the stock market show a positive correlation.

In general, when the stock market is in a bull market, investors have a good expect of the future operation of the listed companies, and the listed companies will have adequate will to expand its operations by M\&A activity, and cash merger and shares merger will in turn promote the rise of stock index. Here we use the Stock Exchange composite index to reflect situation of the stock market. Assumptions 3: M\&A activity and the degree of monetary tightening have a positive correlation.

When the money supply is relatively tight, without sufficient funds, SMEs (small and medium enterprises) will face higher financing costs, while for large enterprises in good standing, the risk premium investors demanding is relatively small and the cash flow to them is consequently large. At this time, SMEs will often become acquisition targets. Here we use the money supply as the extent of monetary tightening. The smaller money supply shows the larger extent of monetary tightening. Assumptions 4: M \& A activity and currency exchange rate changes have positive relations.

Domestic currency appreciation, on the one hand would cause a large inflow of international capital, such capital through mergers and acquisitions to participate in the operation of domestic enterprises, with a view to obtaining profits, on the other hand the cost of foreign acquisition for domestic enterprises will also reduce, stimulating the acquisition of foreign companies.

Assumptions 5: M \& A activity and the level of interest rates correlate negatively.

Investment opportunities depend on the cost of capital. High cost of investment means that fewer investment opportunities. The interest rate level reflects the price that the enterprises must pay for their finance. The higher interest rates, the higher cost the enterprises must pay for their M\&A and the investment opportunities through M\&A would also be smaller. Use semi-annual loan interest rates to reflect the level of interest rates.

Assumptions 6: M \& A activity and the degree of economic freedom are positively correlated.

The higher level of a country's free market, the bigger possibility of the enterprises to effective allocate resources through M\&A approach, then the more active the M\&A between enterprises. Here use the economic freedom index co-prepared by the Heritage Foundation and the "Wall Street Journal," to indicate the degree of economic freedom. 


\subsection{Variable selection}

Usually the overall deal size is demonstrated in two ways, namely, the number of mergers and acquisitions transaction amount. Due to data availability and comparability, we adopt the number of $\mathrm{M} \& \mathrm{~A}$ transactions as the overall size of the acquisition.

According to this paper ideas and hypotheses, the interpretation and definition of the variables involved in the paper can be seen in Table 2 .

Table 2. Variables demonstration

\begin{tabular}{l|ll}
\hline $\begin{array}{l}\text { Variable } \\
\text { Independent } \\
\text { Variable }\end{array}$ & MA & definition \\
\hline $\begin{array}{l}\text { Dependent } \\
\text { Variables }\end{array}$ & GDP & the number of enterprise M\&A activity \\
& STOCK & $\begin{array}{l}\text { gross domestic product } \\
\text { the average of the highest point of the shanghai Exchange Index } \\
\text { and Shenzhen Exchange Index within one year }\end{array}$ \\
& M2 & $\begin{array}{l}\text { sum of narrow money and time deposits, savings deposits and } \\
\text { foreign currency deposits } \\
\text { the medium price of 100 dollar exchange for RMB } \\
\end{array}$ \\
& EXRATE & six-month loan rates \\
& ECFD & economic freedom index produced by U.S Heritage Foundation \\
\hline
\end{tabular}

\subsection{Samples and data sources}

We use the 1996-2006 annual data, after relevant data processing from "China Securities News". GDP data stem from the National Bureau of Statistics website. The data of interest rates, stock index, exchange rate and money supply come from the site of the People's Bank of China Annual statistics, with economic freedom from the Heritage Foundation website. We use SPSS13.0 for statistical analysis.

M\&A data base on the date of the declaration. The inter-departmental merger study found that before several months the merger agreement announced the merger information will appear in the market. Therefore, we make average of the former and current value of all the independent variables. Furthermore, in order to facilitate the statistics, we will take all the variables of data on the number of natural log.

\subsection{Model description}

Based on the above assumptions, we establish the following regression model.

$\mathrm{LnMA}=\beta_{0}+\beta_{1} \ln \mathrm{GDP}+\beta_{2} \operatorname{lnSTOCK}+\beta_{3} \operatorname{lnM} 2+\beta_{4} \operatorname{lnEXRATE}+\beta_{5} \operatorname{lnR}+\beta_{6} \operatorname{lnECFD}+\varepsilon$

\section{Empirical analysis and results}

\subsection{The description of the statistics characteristics}

Table 3. The descriptive statistics of all the variables in the samples

\begin{tabular}{|l|l|l|l|l|l|}
\hline variables & $\begin{array}{l}\text { Number } \\
\text { of sample }\end{array}$ & minimum & maximum & average & $\begin{array}{l}\text { standard } \\
\text { deviation }\end{array}$ \\
\hline MA & 11 & 9 & 1411 & 235.82 & 396.35 \\
\hline GDP & 11 & 71176.6 & 209407 & 121965.9 & 45347.77 \\
\hline STOCK & 11 & 2494.99 & 4763.6 & 3235.51 & 685.97 \\
\hline M2 & 11 & 76094.9 & 345577.9 & 180824.5 & 89044.7 \\
\hline EXRATE & 11 & 782.38 & 831.42 & 823.3 & 13.89 \\
\hline R & 11 & 5.04 & 9.18 & 5.98 & 1.29 \\
\hline ECFD & 11 & 50.6 & 55.4 & 52.69 & 1.78 \\
\hline
\end{tabular}

\subsection{The empirical result}

\subsubsection{Model fitting degree and significant test}

Before we get the positive results, we must firstly determine whether the model is appropriate. According to fitting degree from the model (Table 4), the correlation coefficient $\mathrm{r}=0.996, R^{2}=0.983$, adjusted $R^{2}=0.983$, all of which 
demonstrate that the sample regression model is highly representative. Furthermore, $F=117.054, p<0.001$, the model is significant. We can conclude that these independent variables can explain the dependent variable. Therefore, we can use the model for analysis.

Table 4. Model fitting degree of test results

\begin{tabular}{|l|l|l|l|}
\hline$R$ & R Square & Adjusted R Square & Std. Error of The Estimate \\
\hline 0.996 & 0.992 & 0.983 & 0.172511 \\
\hline
\end{tabular}

Table 5. Variance analysis table

\begin{tabular}{|l|l|l|l|l|l|}
\hline & $\begin{array}{l}\text { Sum of } \\
\text { Squares }\end{array}$ & df & Mean Square & F & Sig. \\
\hline Regression & 17.418 & 5 & 3.484 & 117.054 & .000 \\
\hline Residual & 0.149 & 5 & $2.976 \mathrm{E}-02$ & & \\
\hline Total & 17.566 & 10 & & & \\
\hline
\end{tabular}

a. Predictors: (Constant), GDP, M2, EXRATE, R, ECFD

b. Dependent Variable: MA

\subsubsection{Positive Results}

Table 6 results show that at 1 percent of the significant level, the exchange rate level has significant impact to corporate mergers . The coefficient of -0.577 indicates that the appreciation of the RMB has positive relations with the enterprise merger activity, which verified that the assumption 4 is applicable in China.

At 5 percent of the significant level, the interest rate variable passed through the test. The regression coefficient of -1.561 told us that the level of interest rates and changes in merger activity showed reverse relation that is, the lower the interest rate level, the more active corporate merger activity, which assumed that the assumption is appropriate for China.

At 10 percent of the significant level, the independent variables of GDP and money supply also passed through the examination. The GDP regression coefficient is 4.015 , showing that the higher level of the domestic economy, the more active merger activity, proved the applicability of assumption 1 in China. The money supply regression coefficient is -4.822 , which indicates that the money supply and business merger activities came into a reverse relation. It means that the tightened money supply stimulated merger activity, which made the assumption 3 was verified in China.

However, assuming 2 and 6 did not pass the test. From Table 7 it can be seen that the Stock variables did not enter the equation, this shows that $\mathrm{M} \& \mathrm{~A}$ activity is not significantly affected by the changes of stock market. Although economic freedom variable came into the equation, it did not pass significant test, which also showed that business merger activity has not significantly affected by the level of economic freedom.

Table 6. return to the correlation coefficient table

\begin{tabular}{|l|l|l|l|l|l|}
\hline & \multicolumn{2}{|l|}{$\begin{array}{l}\text { Unstandardized } \\
\text { Coefficients }\end{array}$} & $\begin{array}{l}\text { Standardized } \\
\text { Coefficients }\end{array}$ & $\mathrm{t}$ & Sig. \\
\hline & $\mathrm{B}$ & Std.Error & Beta & & \\
\hline (Constant) & 532.627 & 123.902 & & 4.299 & .008 \\
\hline GDP*** & 15.189 & 7.204 & 4.015 & 2.108 & .089 \\
\hline M2*** & -12.695 & 5.988 & -4.822 & -2.120 & .088 \\
\hline Exrate* & -72.599 & 15.182 & -0.577 & -4.782 & .005 \\
\hline $\mathrm{R}^{* *}$ & -9.564 & 2.506 & -1.561 & -3.816 & .012 \\
\hline Ecfd & -12.163 & 6.070 & -.248 & -2.004 & .101 \\
\hline
\end{tabular}

a Dependent Variable: MA

b Variables which enter into the equation are GDP, M2, Exrate, R, Ecfd. Variable which do not enter the equation is the variable Stock. *, $* * * * *$ were expressed at $1 \%, 5 \%$ and $10 \%$ of the level significantly.

Table 7. The variables which do not enter the equation 


\begin{tabular}{|l|l|l|l|}
\hline variable & Beta & $\mathrm{t}$ & $\mathrm{Sig}$ \\
\hline Stock & -631.614 & -1.997 & .116 \\
\hline
\end{tabular}

\section{Conclusions and inspiration}

After we looked back the past 11 years of mergers and acquisitions of Chinese enterprises, we found that:

(1) M \& A activity responded to the gross domestic product. In recent years with the domestic economy rapid development, China's merger and acquisition activity has greatly increased. This coincided with Nelson (1959), Chung, Kwang S (1981).It can prove that economic development will stimulate and promote merger and acquisition activity.

(2) Stock index and M \& A activity showed an insignificant relation. It is totally different from Nelson (1959), Melicher, Ledolter, Antonio (1982), but similar to Michael Gort, Geraldo, Rechard (1996). We can interpret it from two prospects. Firstly, compared to the international capital markets mature, China's policy has strong influence on stock market, therefore stock prices can not be viewed as a business activity indicator. Secondly, before the split share structure reform, the stock market's outstanding shares are only small part of all company stocks, and consequently plays limited role in business decision-making.

(3) M \& A activity and the money supply showed a negative relation, different from Tang Shaoxiang (2006). We believe that the money supply shortage means that the monetary tightened, and it makes Chinese SMEs more difficult to obtain bank loans, and direct financing channels are very limited, which makes them easily mergered by large enterprises.

(4) M \& A activities and the exchange rate have a significantly positive relation, inconsistent with Geraldo, Rechard (1996), Tang Shaoxiang (2006). It is related with the currency appreciation cycle. On one hand due to expected appreciation of the RMB, a great amount of "hot money" flew into China, and the acquisition of foreign capital has suddenly increased, on the other hand, the appreciation of the RMB also stimulated the Chinese enterprises to go abroad to merge and acquire foreign enterprises.

(5) M \& A activities and level of interest rates show an inverse correlation, consistent with Becketti (1986). In recent years in order to stimulate investment, China continued lowering interest rates. It reduced the cost of corporate mergers and acquisitions, making large-scale mergers and acquisitions more possible.

(6) The relation between $M \&$ A activity and the level of economic freedom is not significant. This is not consistent with our assumption before. This possible explanation is that the economic freedom index published by the Heritage Foundation's is not very good at reflecting the level of the true situation in China. The level of economic freedom in 2001-2005 was not as high as it in 1997, inconsistent with the actual level. This may be one of the reasons why it did not pass the test.

Through the above analysis we can draw that, in recent years China's rapid economic growth, excessive money supply growth, the appreciation of the RMB and a lower level of interest rates jointly promote the corporate mergers and acquisitions. And in the next few years, the expected appreciation of the RMB is likely to encourage enterprises to increase the merger activity, while under high inflation risk the uncertainty of the economy prospect especially, money supply tightening and high possibility of increasing interest rates may also be factors inhibiting the corporate merger activity.

\section{References}

George Bittlingmayer, Merger as a Form of Investment, KYKLOS, 49, 127-53.

Geraldo, M.Vasconcellos and Richard J. Kish. (1996). Factors Affecting Cross-Border Mergers and Acquisitions: The Canada-U.S. Experience. Global Finance Journal, 7, 223-28.

Globe, Devra L and White Lawrence J (2001). Catch a Wave: The Time Series Behavior of Mergers. The Review of Economics and Statistics, 493-99.

Globe, Devra L, and Lawrence J. White, a Time Series Analysis of Mergers and Acquisitions in the U.S Economy, Corporate Takeover: Causes and Consequences, Chicago: NEBR and University of Chicago Press.

Gort, Michael (1969). An Economic Disturbance Theory of Mergers. Quarterly Journal of Economics, 83, 624-42.

Gregor Andrade, Mark Mitchell, and Erik Stafford. New Evidence and Perspectives on Mergers, Journal of Economic Perspectives, 15, 103-20.

Gu Wenjun (2003). The Correlation Study of Chinese Merger and Acquisition and Macro Economic Cycle. Northern Economy and Trade, 10, 12-14 
Halpern, P.J., Empirical Estimates of the Amount and Distribution of Gains to Companies in Mergers, Journal of Business, 46, 554-75.

Hemant Merchant. Merger Strategies and Shareholder Value during Times of Relaxed Antitrust Enforcement: The Case of Large Mergers during the 1980s. Journal of Management, 23, 59-81.

Li Ruihai, Chen Hongmin, and Zou Lirui (2006). Investigation on Evidence of Macroscopic Factors Influencing the Merger of Corporations in China. Management Review, 18, 50-53

Nelson, Ralph L. (1959).Merger Movement in American Industry, 1895-1956. Princeton: Princeton University Press for the National Bureau of Economic Research.

Weston, J.Fred, Chung S Kang, and Hoag E Susan (2005). Merger, Restructuring, and Corporate Control, Prentice Hall, Chapter10. 